\title{
21. ANALYSIS AND INTERPRETATION OF X-RAY IMAGES OF SEDIMENT CORES FROM HOLE 910D, YERMAK PLATEAU: PRELIMINARY RESULTS ${ }^{1}$
}

\author{
Frank R. Rack, ${ }^{2}$ Rustan Finndin, ${ }^{3}$ and Kate Moran ${ }^{4}$
}

\begin{abstract}
Ocean Drilling Program Hole 910D was drilled on the crest of the southern Yermak Plateau at $80^{\circ} 15.881^{\prime} \mathrm{N}, 6^{\circ} 65.424^{\prime} \mathrm{E}$, in $567.7 \mathrm{~m}$ water depth. This hole consists of three cores recovered with the advanced hydraulic piston corer (APC) and 15 cores recovered with the extended core barrel (XCB), penetrating to a total depth of 160.6 meters below sea floor (mbsf). Three earlier holes were drilled at this site, but two of them (Holes 910A and 910B) failed to penetrate through a stiff horizon at about 20-24 mbsf, and a third hole (Hole 910C), drilled using the rotary core barrel (RCB), yielded poor core recovery in the upper 200 mbsf.

As a first step in the study of individual core sections from Hole 910D, non-destructive, whole-core X-ray examinations were performed at the Atlantic Geoscience Center of the Bedford Institute of Oceanography in Dartmouth, Nova Scotia, Canada. Using a high-resolution video monitor, X-ray images of almost $96 \mathrm{~m}$ of core were visually examined and described; these $\mathrm{X}$-ray images were simultaneously recorded on video tape for further digital processing and interpretation.

Videotaped X-ray images of the Hole 910D core sections have been used to identify the relative position and size of individual clasts ( $>2 \mathrm{~mm}$ in diameter) and coarse sand layers, and to identify extensively bioturbated intervals, represented by burrow traces in these cores. Solid particles $>2 \mathrm{~mm}$ in diameter, were counted for successive 10 - $\mathrm{cm}$ intervals of core using the video X-ray images. The X-ray images provide "ground truth" for making comparisons with other nondestructive measurements made on these cores using sensors mounted on the multisensor track (MST), and for identifying changes in depositional environments at this site.
\end{abstract}

\section{INTRODUCTION}

\section{Background}

The northern basins of the Norwegian-Greenland Sea and Arctic Ocean are important to paleoclimatic and paleoceanographic studies because they exert a pivotal role in the modern climate system by providing the primary Northern Hemisphere source of deep-water production in the world ocean (Aagaard et al., 1985). The NorwegianGreenland Sea is linked to the Arctic Ocean by the Fram Strait, which separates the islands of Svalbard from Greenland (Fig. 1) and provides a convenient route for the transport of sediment-laden ice from the circum-Arctic Ocean shelf into the Norwegian-Greenland Sea. Fram Strait also plays a prominent role in the exchange of water masses between these two basins (Fig. 2; for reviews of the modernday oceanography of these regions, see Hunkins, 1990; Hopkins, 1991; Manley et al., 1992).

The continental margins surrounding the Norwegian-Greenland Sea have undergone extensive periods of widespread glaciation during the Quaternary. However, there is considerable debate as to the exact timing of glacial advances/retreats on and around Svalbard (Andersen et al., 1992; Boulton, 1979; Forman, 1989, 1990; Hebbeln, 1992; Hebbeln et al., 1994; Jones and Keigwin, 1988; Lehman and Forman, 1992; Mangerud and Svendsen, 1990, 1992; Mangerud et al., 1992; Miller et al., 1989; Salvigsen, 1979; Salvigsen and Österholm, 1982; Svendsen and Mangerud, 1992; Svendsen et al., 1992) and in the Barents Sea (Eidvin et al., 1993; Elverhøi, 1984; Elverhøi and Solheim, 1983, 1987; Polyak et al., 1995; Solheim et al., 1988,

'Thiede, J., Myhre, A.M., Firth, J.V., Johnson, G.L., and Ruddiman, W.F. (Eds.), 1996. Proc. ODP, Sci. Results, 151: College Station, TX (Ocean Drilling Program).

${ }^{2}$ Ocean Mapping Group, Department of Geodesy and Geomatics Engineering, University of New Brunswick, Fredericton, NB, E3B 5A3, Canada. rack@omg.unb.ca

${ }^{3}$ Chalmers University of Technology, Department of Naval Architecture and Ocean Engineering, Division of Underwater Technology, S-412 96 Gothenburg, Sweden.

${ }^{4}$ Geological Survey of Canada, Bedford Institute of Oceanography, Box 1006, Dartmouth, NS, B2Y 4A2, Canada.

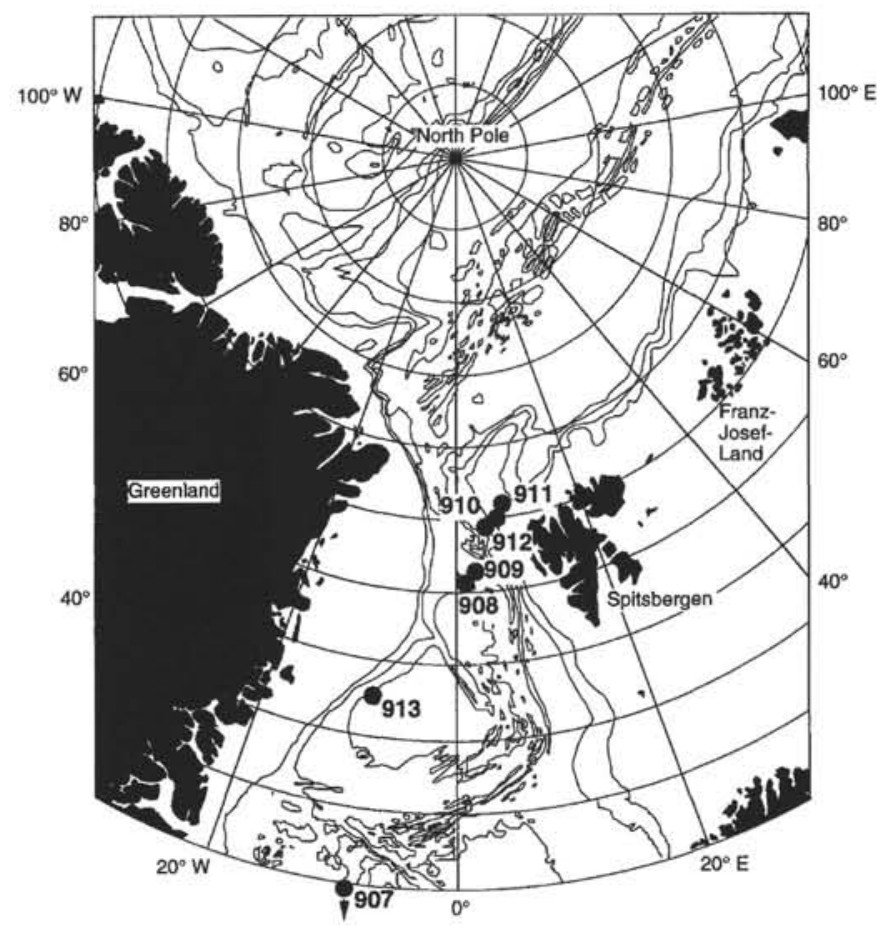

Figure 1. Bathymetric map of the northern Norwegian-Greenland Sea and Arctic Ocean, showing the location of Fram Strait between Spitsbergen and Greenland, and the northern boundary of the Barents (south and east of Spitsbergen) and Kara Seas (east of Franz-Josef-Land). The locations of the Leg 151 sites are also shown (from Stein et al., 1994). 




Figure 2. Upper-layer circulation patterns of the various currents in the northern Greenland Sea, Yermak Plateau, and surrounding areas (from Myhre, Thiede, Firth, et al., 1995; Manley et al., 1992). The West Spitsbergen Current, an extension of the Norwegian Current, transports temperate Atlantic waters through the Fram Strait to the edge of the Arctic sea ice, where these waters are either recirculated into the southward-flowing East Greenland Current or continue into the Arctic Ocean under the sea-ice cover.

1990). There is also considerable debate regarding the thickness and geographic distribution of paleo-ice sheets in the region (Denton and Hughes, 1981; Elverhøi et al., 1993; Forman, 1990; Forman et al., 1995; Grosswald, 1980, 1993; Lambeck, 1995).

As glaciers expand, they compress the sediments over which they flow; this compression results in the overconsolidation of sediments, as indicated by higher shear strengths and bulk densities measured in recovered cores. Even though the sediments swell upon glacier retreat, they still retain a "memory" of their past glacial consolidation. Higher values of bulk density measured in cores may, alternatively, reflect an increase in the percentage of dropstones and coarse-grained material in the bulk sediment, possibly caused by changes in the proximity of the ice-grounding line of a glacier or ice sheet, and/or by changes in the intensity of ice-rafting in the region.

\section{Leg 151 Drilling on Yermak Plateau}

The JOIDES Resolution (Sedco/BP 471) recovered the first scientific drill cores from the eastern Arctic Ocean during Ocean Drilling Program (ODP) Leg 151 (Myhre, Thiede, Firth, et al., 1995). Sedimentary records retrieved from three sites located near $80^{\circ} \mathrm{N}$ on Yermak Plateau form a southwest-northeast-oriented transect across the southern part of the plateau, from the western slope in Fram Strait toward the Arctic Ocean (i.e., from Site 912 towards Site 911; see Fig. 1). This paper will address the Late Pliocene to Quaternary sediment record recovered at Site 910, on the crest of Yermak Plateau, where four holes were drilled.

The sedimentary sequence recovered in Hole 910A consists of very firm, predominantly very dark gray, nearly homogeneous silty clays and clayey silts (Myhre, Thiede, Firth, et al., 1995). Steep gradients in sediment strength $(<50$ to $>250 \mathrm{kPa})$ and bulk density $(1.7$ to $2.2 \mathrm{~g} / \mathrm{cm}^{3}$ ) were observed between the seafloor and 20-25 mbsf in Hole 910A (Fig. 3). Non-destructive bulk density measurements were made on whole-round cores using the gamma ray attenuation porosity evaluator (GRAPE) mounted on the shipboard multisensor track, while sediment strength was determined using both the vane shear device and the pocket penetrometer.

The lowermost sediments recovered in Hole 910A consisted of a stiff, coarse-grained "diamicton" that was interpreted to be overconsolidated. At Hole $910 \mathrm{C}$, rotary coring produced extremely poor core recovery in the upper $200 \mathrm{mbsf}$; however, high sediment strengths $(150-250 \mathrm{kPa})$ and increased numbers of large ( $>1-\mathrm{cm}$ in diameter) dropstones were observed in the recovered sediment above about 40 mbsf (Fig. 4; Myhre, Thiede, Firth, et al., 1995).

The stiff, overconsolidated interval at Site 910 can be traced along the Yermak Plateau in seismic reflection records. The near-surface seismic reflectors at Site 910, which are interpreted to correspond with lithostratigraphic Subunit 1A (Fig. 5; Myhre, Thiede, Firth, et al., 1995), appear chaotic and acoustically transparent. However, the surficial seismic reflectors become more coherent and acoustically stratified away from Site 910, both northeastward toward Site 911, and southwestward toward Site 912 . In $3.5 \mathrm{kHz}$ profiles around Site 910 (see Myhre, Thiede, Firth, et al., 1995), the irregular character of the seafloor may suggest iceberg grounding on the seafloor. Vogt et al. (1994), have identified numerous relict iceberg plowmarks at present water depths from $<450 \mathrm{~m}$ to at least $850 \mathrm{~m}$ on the Yermak Plateau.

\section{Hole 910D}

Hole 910D was drilled on the crest of the southern Yermak Plateau at $80^{\circ} 15.881^{\prime} \mathrm{N}, 6^{\circ} 35.424^{\prime} \mathrm{E}$, in 567.7 meters of water (1). Hole $910 \mathrm{D}$ consists of three cores recovered with the advanced hydraulic piston corer (APC) and 15 cores recovered with the extended core barrel (XCB), penetrating to a total depth of 160.6 meters below seafloor (mbsf). The core recovery from the seafloor to $18.6 \mathrm{mbsf}$ using the APC, was $99.7 \%$; recovery decreased in the interval from 18.6 to 160.6 mbsf to only $59.8 \%$ of the advanced length of pipe using the $\mathrm{XCB}$.

The main objective of this paper is to present the results of nondestructive, X-ray imaging of whole-round sediment cores from Hole $910 \mathrm{D}$ on Yermak Plateau (Fig. 6). The X-ray images are used (1) to identify the relative position and size of individual clasts $(>2 \mathrm{~mm}$ in diameter) and coarse sand layers in successive $10-\mathrm{cm}$ intervals of sediment, and (2) to identify the intervals of extensively bioturbated sediments in these cores, represented by burrow traces. We will present some preliminary interpretations of the X-ray results and will compare the record from Hole 910D with recent interpretations of the glacial history of the Svalbard and Barents Sea ice sheets in the final section of this paper.

\section{METHODS Shipboard Core Handling}

Hole 910D was cored to provide samples for use in post-cruise geotechnical testing of sediments under in situ pressures and controlled environmental conditions in shorebased laboratories. Shipboard core handling practices were used to: (1) prevent moisture loss in cores, (2) maintain their vertical orientation, and (3) limit the postrecovery disturbance of these cores. Shortly after recovery, each core section was passed through the sensors mounted on the shipboard multi-sensor track (MST), to collect measurements of GRAPE bulk density, magnetic susceptibility, $P$-wave velocity, and natural gamma activity. Following these measurements, each section was wrapped with electrical tape and dipped in a mixture of beeswax and paraffin to prevent moisture loss during storage. The cores were then 

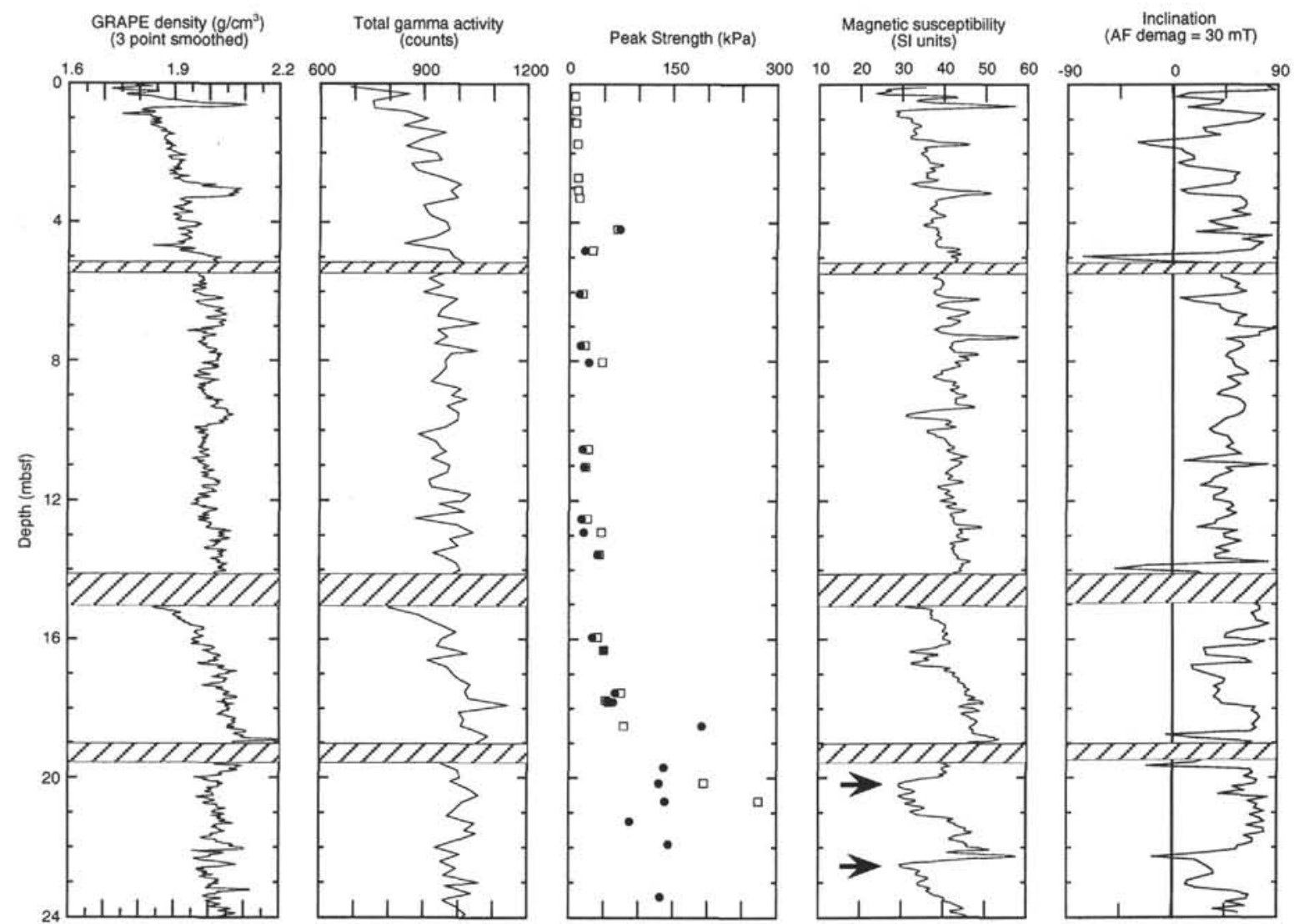

Figure 3. Summary plots of whole-core measurements of GRAPE bulk density, total gamma activity, and magnetic susceptibility made on Cores $151-910 \mathrm{~A}-1 \mathrm{H}$ through 4H (Myhre, Thiede, Firth, et al., 1995). Also shown are split-core measurements of peak strength (solid circles = vane shear; open squares = penetrometer), and natural remanent magnetization (NMR) inclination values (after alternating field [AF] demagnetization to $30 \mathrm{mT}$ ). Regions of diagonal shading indicate core boundaries. The solid arrows indicate the position of two horizons that provide possible correlations between Holes 910A and 910D (see Fig. 10).

stored upright in a refrigerated container to maintain their orientation relative to the vertical (principle) stress axis.

\section{Shorebased Investigation}

Post-cruise investigations of the core sections from Hole 901D have involved the preliminary description of $96 \mathrm{~m}$ of individual core sections using a vertically oriented X-Ray system located at the Atlantic Geoscience Center (AGC) core repository of the Bedford Institute of Oceanography (BIO) in Dartmouth, Nova Scotia, Canada. A general description of X-radiography, as applied to sediments, is provided by Bouma (1979). The X-ray images provide "ground truth" for making comparisons with other nondestructive measurements made on these cores, including measurements of (1) GRAPE bulk density, (2) bulk magnetic susceptibility, and (3) natural gamma activity (Fig. 6). Changes in these properties may reflect changes in sediment grain size distributions, lithology, source region, and/or depositional environment. In this paper, the terms "clast" and "particle" will both be used to refer to rocks or aggregates $>2 \mathrm{~mm}$ in diameter, observed in the X-ray images.

The X-ray imaging system (Fig. 7) consists of an X-ray source located in a shielded room, with the motion controller and recording/ viewing devices for the system operator housed in an adjoining room. The core was placed in a plastic housing to provide support and was then moved through the X-ray beam by a continuous screw drive controlled by a "joy-stick," which allowed the operator to manually control the vertical and rotational motions of the core during scanning.

Each core section was placed in the X-ray beam with the workinghalf of the core facing the X-ray source. The typical procedure was to scan the core vertically three times (i.e., at $0^{\circ}$ and $90^{\circ}$ of rotation, and with full manual rotation at selected intervals) to assess the distribution of various particles within the core liner and to look for specific features. An adjustable aperture on the X-ray source ensured that the $\mathrm{X}$-rays were only passing through the thickest portion of the core (4$\mathrm{cm}$-wide window vs. a $6.6 \mathrm{~cm}$ diameter core) and not through the rounded edges, where variable sediment thickness and/or disturbance could influence the quality of the images (and data) being collected.

The X-ray images from each core section were displayed on a viewing monitor and were simultaneously recorded on videotape. The video recording system allowed the operator to annotate the video frames recorded for each core section with the standard ODP information (Leg-Hole-Core-Type-Section). A written description of each core section was made by the operator during the systematic scans to preserve a hard copy of the initial image interpretation in case something happened to the tapes.

\section{Digital Capture and Processing of Video X-ray Images}

The video images were digitized using a Macintosh PowerPC computer with the aid of commercial "frame grabbing" software (i.e., VideoShop or FusionRecorder software can be used to grab QuickTime movies, and DeBabelizer software can be used to split movies into single frames). A homegrown software program that runs on a Unix workstation was used to combine parts of single frames into a continuous image mosaic. The entire process, from video sequence, to grabbed video frames, to construction of the strip chart is shown in Figure 8. Captured video X-ray images from Section 151-910D-4X2 are used to illustrate the output of the various steps in the frame 


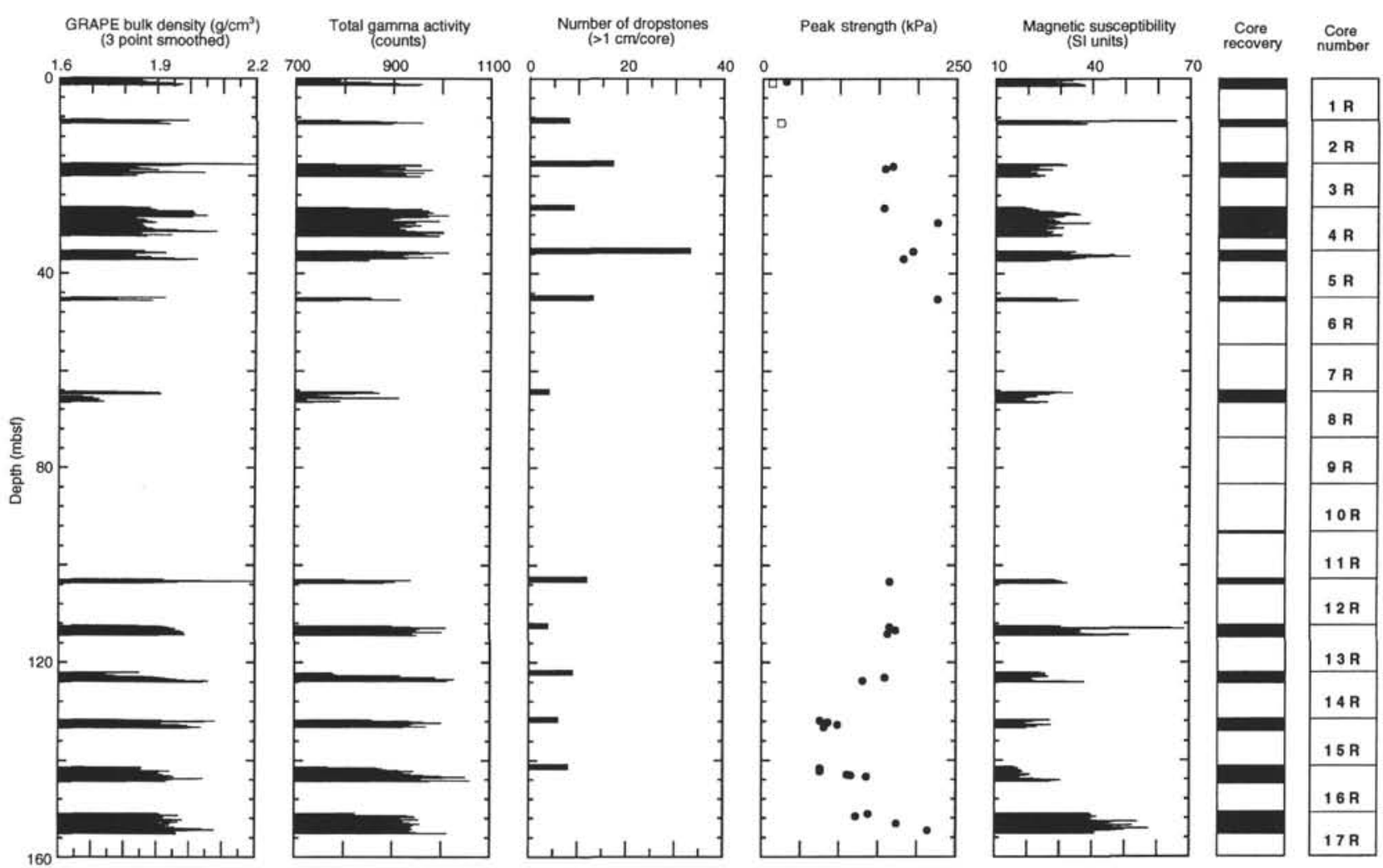

Figure 4. Summary plots of whole-core measurements of GRAPE bulk density, total gamma activity, and magnetic susceptibility made on Cores 151-910C-1R through 17R (Myhre, Thiede, Firth, et al., 1995). Also shown are split-core values of peak strength measurements (solid circles = vane shear; open squares = penetrometer), shipboard counts of the number of dropstones $(>1 \mathrm{~cm})$ per core, and plots of core recovery and boundaries. Note the decrease in strength values in Cores 151-910C-13R through 15R.

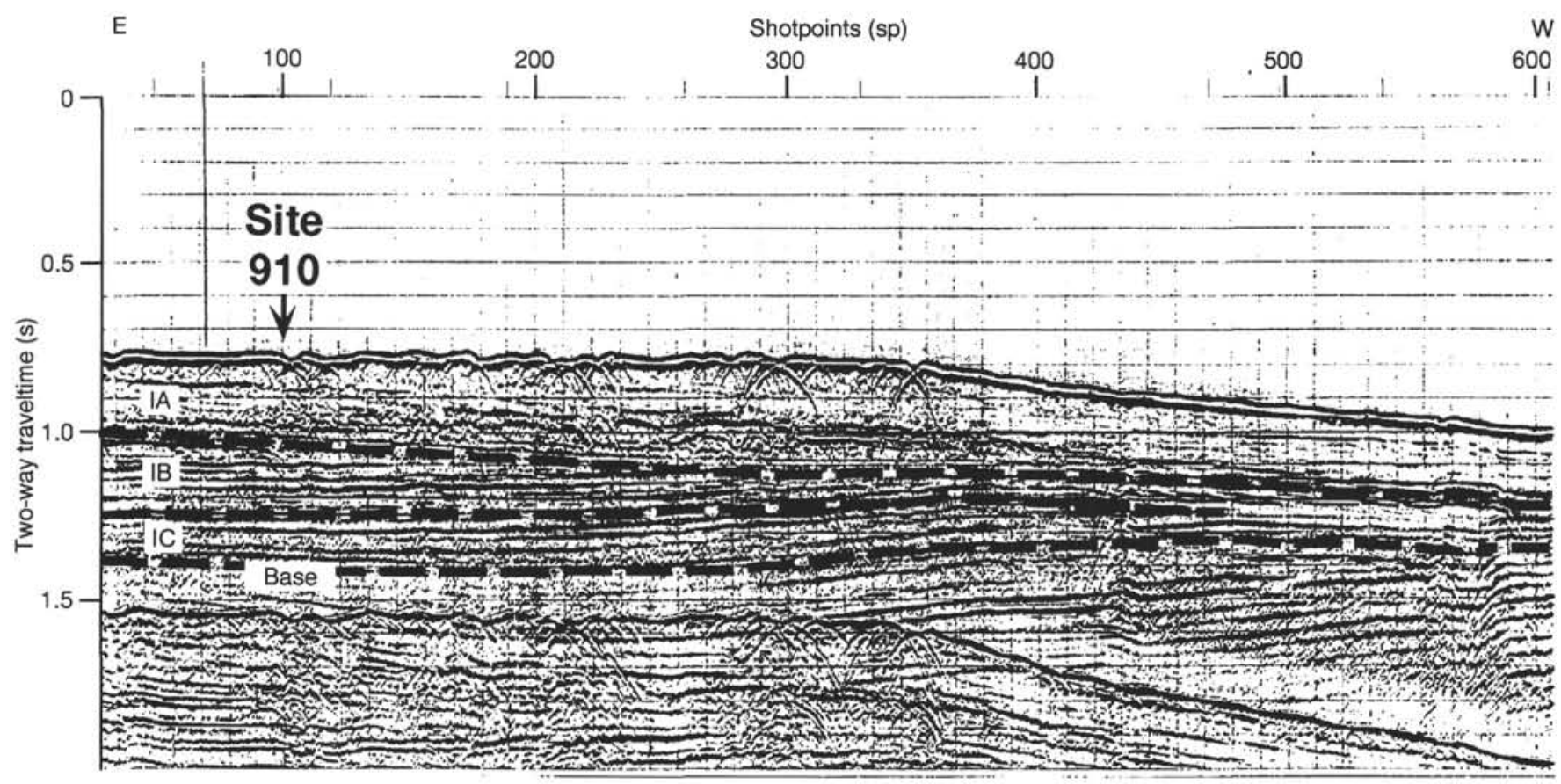

Figure 5. Interpretation of the seismic line AWI-91130 through Site 910 (from Myhre, Thiede, Firth, et al., 1995). The lower Pliocene lithostratigraphic Subunits IB and IC pinch out to the west and seem to be truncated by the overlying subunit in this line, whereas the upper Pliocene/Pleistocene Subunit IA thickens to the shelf edge. Undulations of surface reflectors may reflect relict iceberg plowmarks on the seafloor (see Vogt et al., 1994). 
grabbing, image enhancement, and strip-chart generating process (Fig. 9).

The normal "grabbed" video frame size (NTSC) was $640 \times 480$ pixels (Fig. 9A). Following digital capture, we degraded the region surrounding the core (e.g., the lead shielded region to the left and right of the aperture "window" showing the core) in each video image. This caused the image of the core itself to be enhanced (Fig. 9B). We did this to improve the quality of the X-ray image that would be used in subsequent analyses. If direct digitization of the core image (i.e., without videotape storage) was undertaken in future X-ray im-

Table 1. Drilling statistics, Hole 910D.

\begin{tabular}{lrrrrr}
\hline Core & $\begin{array}{c}\text { Top } \\
(\mathrm{mbs})\end{array}$ & $\begin{array}{c}\text { Bottom } \\
(\mathrm{mbsf})\end{array}$ & $\begin{array}{c}\text { Advanced } \\
(\mathrm{m})\end{array}$ & $\begin{array}{c}\text { Cored } \\
(\mathrm{m})\end{array}$ & $\begin{array}{c}\text { Recovery } \\
(\%)\end{array}$ \\
\hline 1H & 0.0 & 5.8 & 5.8 & 5.79 & 99.8 \\
2H & 5.8 & 14.4 & 8.6 & 8.58 & 99.7 \\
3H & 14.4 & 18.6 & 4.2 & 4.18 & 99.5 \\
$4 \mathrm{X}$ & 18.6 & 27.3 & 8.7 & 3.22 & 37.0 \\
$5 \mathrm{X}$ & 27.3 & 36.3 & 9.0 & 0.80 & 8.9 \\
$6 \mathrm{X}$ & 36.3 & 45.3 & 9.0 & 2.01 & 22.3 \\
$7 \mathrm{X}$ & 45.3 & 54.9 & 9.6 & 1.10 & 11.4 \\
$8 \mathrm{X}$ & 54.9 & 64.5 & 9.6 & 1.71 & 17.8 \\
$9 \mathrm{X}$ & 64.5 & 74.1 & 9.6 & 3.46 & 36.0 \\
$10 \mathrm{X}$ & 74.1 & 83.7 & 9.6 & 4.82 & 50.2 \\
$11 \mathrm{X}$ & 83.7 & 93.4 & 9.7 & 9.50 & 97.9 \\
$12 \mathrm{X}$ & 93.4 & 103.0 & 9.6 & 8.64 & 90.0 \\
$13 \mathrm{X}$ & 103.0 & 112.6 & 9.6 & 9.77 & 102.0 \\
$14 \mathrm{X}$ & 112.6 & 122.3 & 9.7 & 8.52 & 87.8 \\
$15 \mathrm{X}$ & 122.3 & 131.9 & 9.6 & 7.47 & 77.8 \\
$16 \mathrm{X}$ & 131.9 & 141.5 & 9.6 & 7.72 & 80.4 \\
$17 \mathrm{X}$ & 141.5 & 151.1 & 9.6 & 9.05 & 94.3 \\
$18 \mathrm{X}$ & 151.1 & 160.6 & 9.5 & 7.12 & 74.9 \\
\hline
\end{tabular}
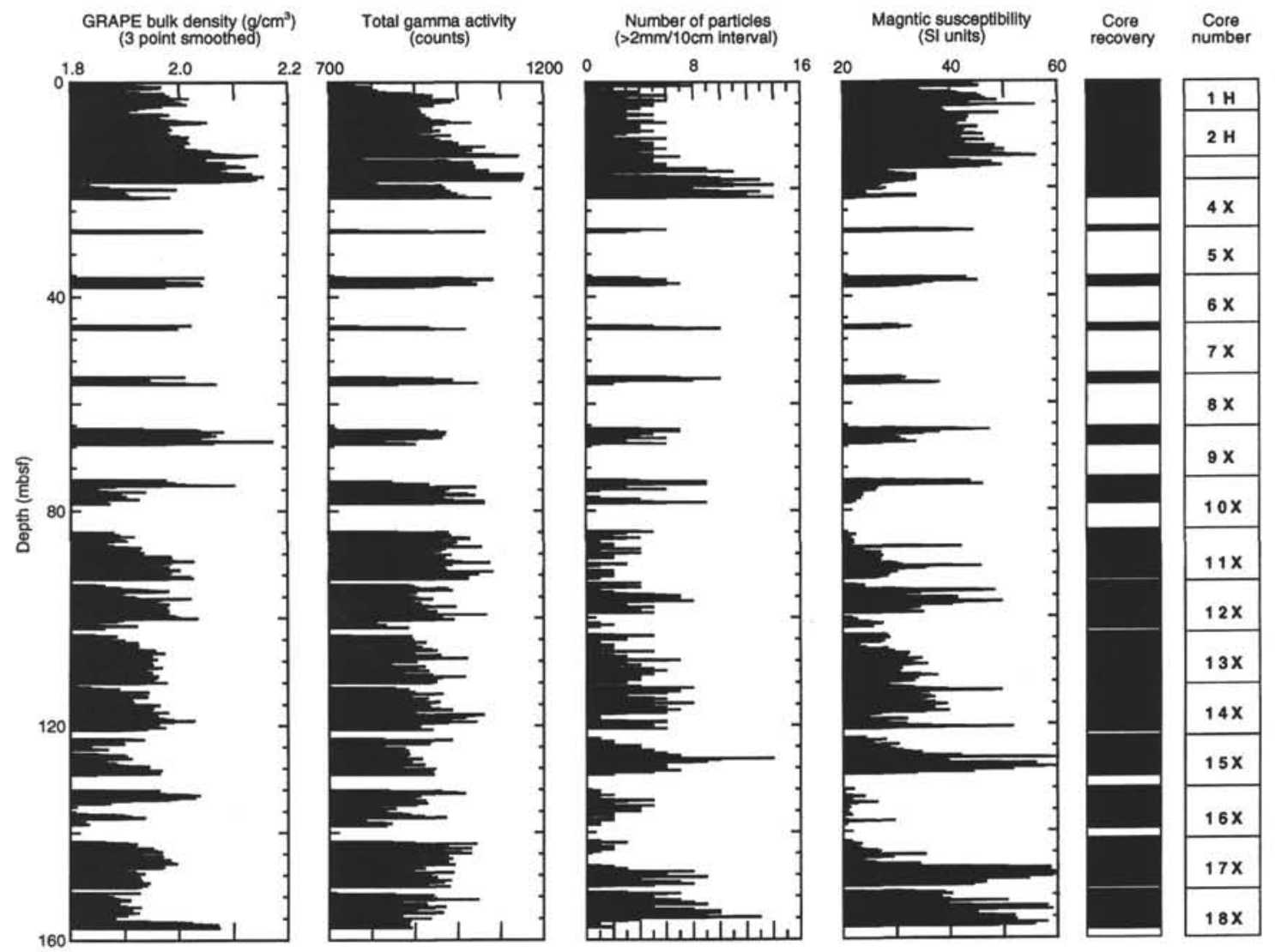

Figure 6. Summary plots of whole-core measurements of GRAPE bulk density, total gamma activity, and magnetic susceptibility made on Cores 151-910D-1H through 18X. Video X-ray images of these cores have been used to count the number of particles $(>2 \mathrm{~mm})$ within each 10 -cm-long interval of core. Plots of core recovery and boundaries are also shown. The largest increase in the numbers of particles $>2 \mathrm{~mm}$ occurs in Cores $151-910 \mathrm{D}-3 \mathrm{H}$ and $4 \mathrm{X}$; this interval also contains a significantly greater number of larger $(>1 \mathrm{~cm})$ dropstones than are observed elsewhere in Hole 910D. Intensely bioturbated (burrowed) intervals of sediment are observed in the X-ray images of Cores 151-910D-10X, 16X, and 17X. aging studies, then greater image quality could be realized without further processing.

The strip-chart generating program takes a sequence of overlapping video frames and builds a spliced image, that is, a mosaic of the areas selected in each video frame (Fig. 9C). The number of video lines that represent the movement from one frame to the next are extracted, and the extracted parts from all frames in the sequence are spliced together into one long image. The actual selection of the number of lines taken from each video frame can be done either manually

The video X-ray images were analyzed using a video cassette recorder and video monitor to identify clasts and burrows preserved in the cores. We counted the number of clasts (i.e., particles $>2 \mathrm{~mm}$ ) in each successive $10-\mathrm{cm}$ interval, using a grid placed directly on the video monitor. The grid helped to make the counting as quantitative as possible.

\section{RESULTS}

\section{Interpretation of the $\mathrm{X}$-ray Images}

Particle counts ranged from minimum values of zero to maximum values of $>14$ particles in a single $10 \mathrm{~cm}$-interval of core (see Fig. 6). A large amount of variability was observed in the clast counts, both in terms of the absolute numbers of particles counted in each interval, and in terms of the average size of the clasts encountered. Cracks, voids, and other indications of core disturbance were readily identified using the video images. or automatically using the strip-chart generating software. 


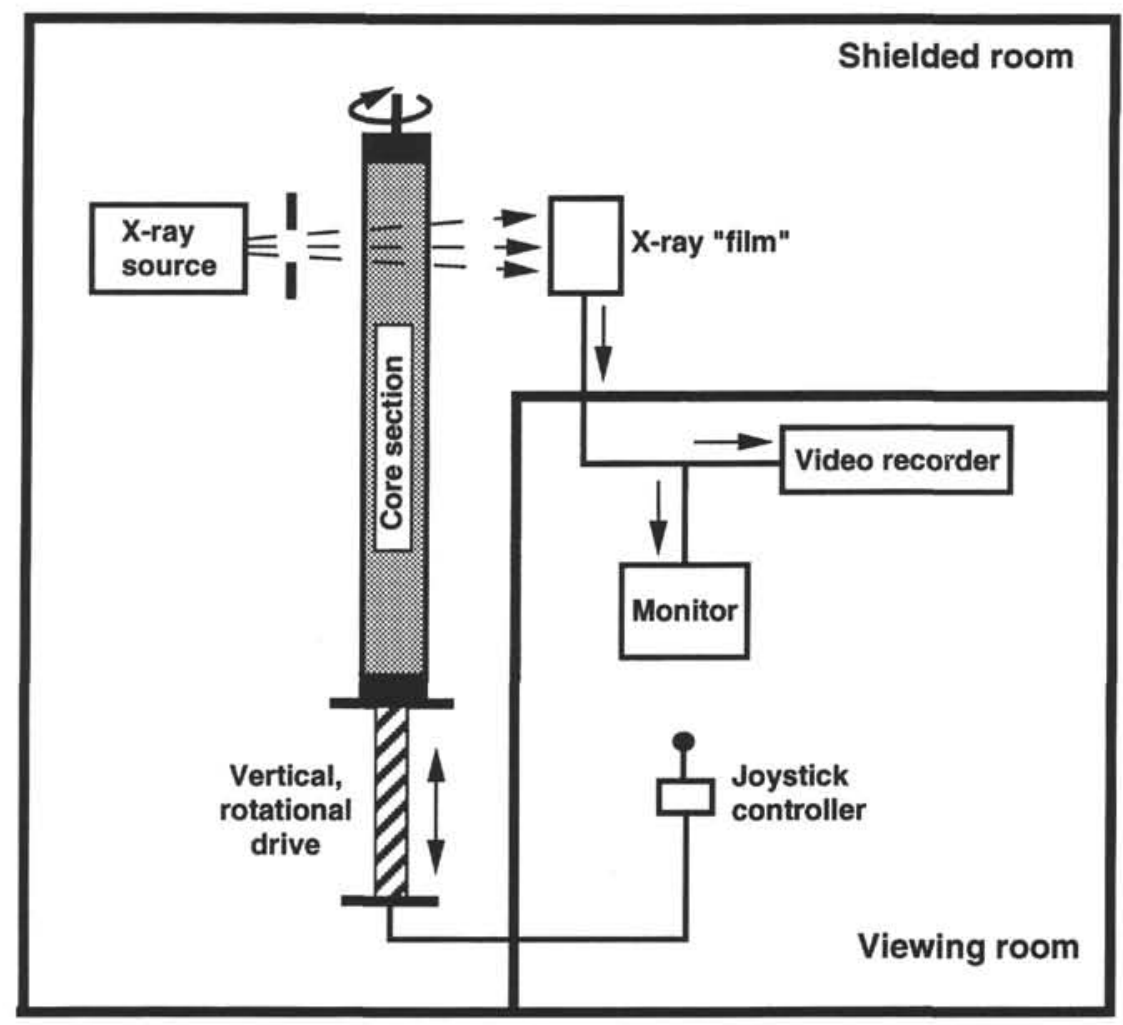

Figure 7. An illustration of the whole-core, X-ray imaging system used in this study. The X-ray source is located in a lead-shielded room that is separated from the operator's viewing room. The viewing room contains the joystick controller for moving and rotating the core within the X-ray beam, a viewing monitor, and a video recorder for archiving the $\mathrm{X}$-ray images of the core.

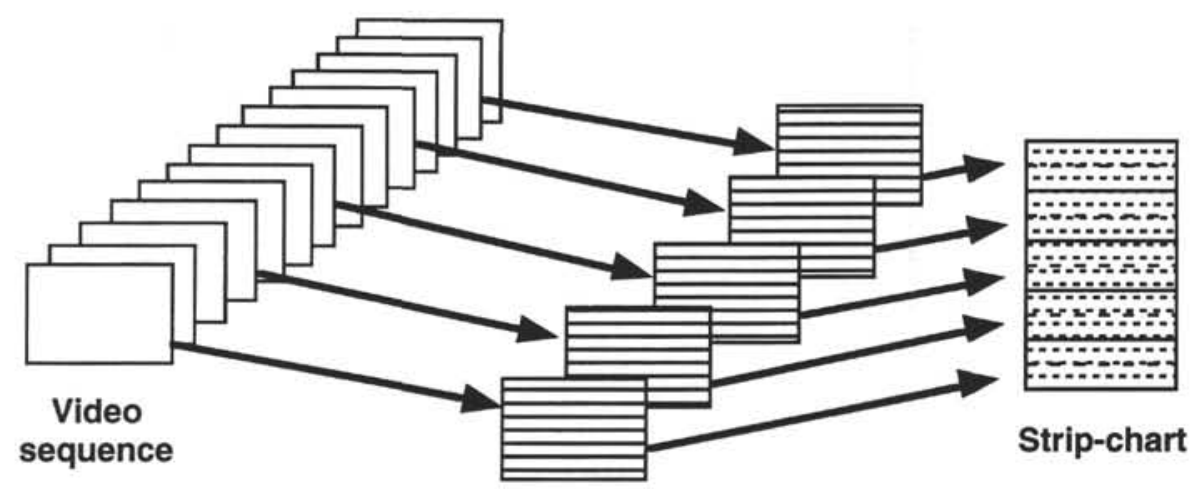

Grabbed video frames

Figure 8. An illustration of the process of digitally capturing ("grabbing") individual video frames from a video sequence, and then constructing a composite strip-chart of selected video "lines" from a series of video frames.

Large numbers of large clasts ( $>1 \mathrm{~cm}$ in diameter) were observed below 16 mbsf in Hole 910D (see Figs. 6 and 10), corresponding to Cores 151-910D-3H and 4X. The captured video images of Section 151-910D-4X-2 (Fig. 9) are generally representative of the average size and distribution of the majority of clasts found in Section 151910D-3H-3 and in Core 151-910D-4X. Whenever large numbers of clasts were observed in the X-ray images from Hole 910D, they were matrix-supported. It was possible to qualitatively differentiate between fine-grained (silty) and coarse-grained (sandy) matrix using the video images of the core sections.
Intervals having no clasts were often composed of extremely homogeneous, fine-grained sediment, having no visible structures in the $\mathrm{X}$-ray images. In some intervals, large numbers of clasts were seen floating in a coarse-grained matrix, while many other intervals exhibited a sandy texture without the presence of significant numbers of clasts.

We have attempted to correlate between the upper four cores in Hole 910D (Fig. 10) and the corresponding interval recovered in Hole 910 A (Fig. 3). This proved to be a difficult undertaking because the multisensor records from the two holes seem to be quite different. 
A
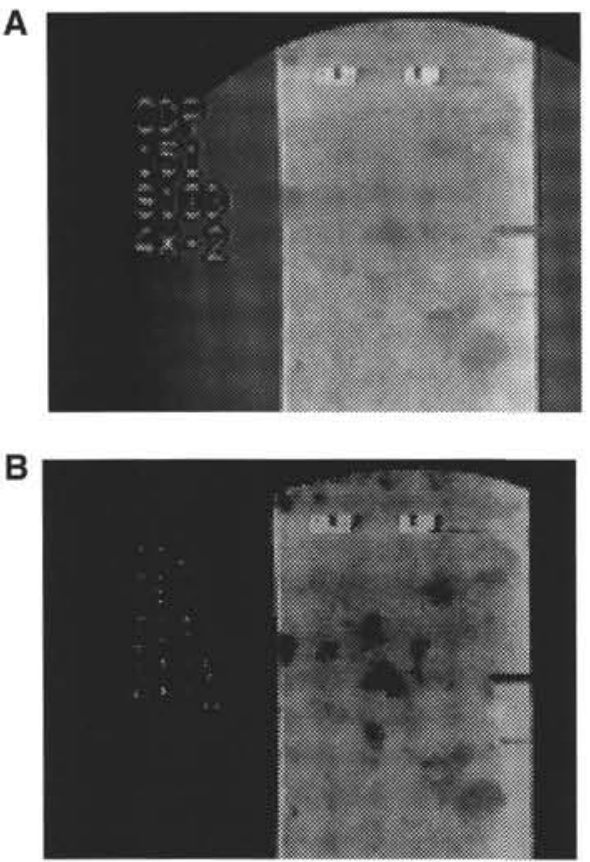

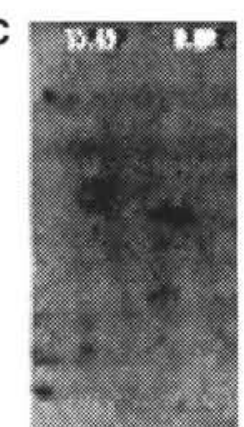

Figure 9. A. Captured X-ray video frame of Section 151-910D-4X-2, (56-64 $\mathrm{cm}$ ); the ODP core identification information is annotated directly onto the video frame. The image is approximately $4 \mathrm{~cm}$ wide by $8 \mathrm{~cm}$ high. The two dark markings along the right side of the core are located $1 \mathrm{~cm}$ apart; they provide a standard reference scale. There are two digital counters located at the upper part of each video frame which record (1) the distance traveled along each core section in centimeters and (2) the degrees of rotation of the core. B. The same video image of Section 151-910D-4X-2, after digital processing to enhance the contrast of particles within the core. The dark shapes in the core image are ice-rafted pebbles of various sizes. C. A 20-cm-long strip-chart image of a portion of Section 151-910D-4X-2, generated from several pieces of individual video frames. The 8-cm-long image shown in A and $\mathrm{B}$ can be seen in the central portion of this strip-chart.

The depths at which APC penetration was terminated in these two holes are also different. This seems to suggest that a part of the sediment record is missing in Hole 910D or that the sequence is expanded in Hole $910 \mathrm{~A}$, or both.

We have compared the multisensor track (MST) data obtained from each hole and have identified a number of similarities that may be significant. There is a GRAPE bulk density peak at about $10 \mathrm{mbsf}$ in Hole 910A that seems to correspond to a similar GRAPE bulk density peak at about $8 \mathrm{mbsf}$ in Hole 910D. Our interpretation is that the sediment contained in Core $151-910 \mathrm{D}-1 \mathrm{H}$ is slightly compressed relative to Hole $910 \mathrm{~A}$ and that some material may be missing between Cores 151-910D-1 $\mathrm{H}$ and $2 \mathrm{H}$. Conversely, the material contained in Core 151-910A-1H may be slightly expanded given that the upper portions of the MST records from Hole 910B and 910D are nearly identical (Myhre, Thiede, Firth, et al., 1995), while the MST records from Hole 910A show quite different characteristics in Core 151910A-1H (compare Figs. 3 and 10).

We measured the natural remanent magnetization (NRM) of selected whole-round cores from Hole 910D, using a pass-through cryogenic superconducting rock magnetometer, belonging to Dr. John King, at the University of Rhode Island. We show NRM inclination values after alternating field (AF) demagnetization to $10 \mathrm{mT}$, for Cores 151-910D-1H through 4X (Fig. 10). These data are not interpreted here, but are used to suggest that similar variations in NRM inclination records are observed in both holes.
A very distinctive feature that is common to these two records is a sharp decrease in magnetic susceptibility values, that is located at about 16.5 mbsf in Hole 910D; this change is associated with negative NRM inclination values and a major increase in the number of clasts observed in X-ray images (Fig. 10). In addition to the increase in clast numbers, there is an increase in the average size of the clasts observed in this interval, which is approximately $3 \mathrm{~m}$ above the APC/ XCB transition in Hole 910D. In Hole 910A (Fig. 3), there are two horizons that might correlate with the susceptibility change observed in Hole 910D. Both of these possibilities are located in Core 151$910 \mathrm{~A}-4 \mathrm{H}$, within the interval of increased sediment strength (i.e., stiff sediment) near the base of this hole.

We suggest that the magnetic susceptibility decrease at about 20 mbsf in Hole $910 \mathrm{~A}$ is the more likely candidate for establishing a correlation with Hole 910D. This implies that APC coring in Hole 910A may have penetrated further into the overconsolidated section than was the case in Hole 910D; although there are likely gaps in the sediment recovery in both holes, and there is a strong possibility that regional variations in sedimentation are quite important in this high-latitude environment.

Core recovery was rather poor in the interval between Cores 151910D-4X and 10X (compare Figs. 4 and 6). The improved recovery in Hole 910D relative to Hole 910C may allow biostratigraphers to fill in many of the gaps in the stratigraphic section and better define the position of the Pliocene/Pleistocene boundary, which is presently located near 80 mbsf in Hole 910C.

There were several intervals in the deeper parts of Hole 910D that were intensely burrowed. These intervals include Section 151-910D$10 \mathrm{X}-1$ through 10X-3, Section 151-910D-11X-3, Sections 151910D-16X-3 through 16X-5, and Sections 151-910D-17X-2 through 17X-3. An abrupt decrease in GRAPE bulk density at approximately 75 mbsf in Hole 910D may be associated with the interval of bioturbation in Core 151-910D-10X. An example of the intensity of burrowing in these intervals is provided by Figure 11, showing a pair of spliced video images from Section 151-910D-10X-2.

Intervals of intensively burrowed core seem to also correspond to intervals with low measured values of magnetic susceptibility in Hole 910D (Fig. 6). In Hole 910C, low susceptibility values are associated with decreased sediment strength in Cores 151-910C-14R through 16R (Fig. 4). The lowered sediment strength may reflect the same increase in bioturbation that is observed in Hole 910D.

\section{DISCUSSION}

\section{Introduction}

The recovery of dedicated cores from Hole $910 \mathrm{D}$ provided a rare opportunity to demonstrate that video X-ray imaging could be used to nondestructively investigate a wide range of depositional and environmental signals preserved in glaciomarine sediments. In the following discussion, we will first attempt to establish the validity of using counts of gravel-size clasts $(>2 \mathrm{~mm})$ as an indicator for iceberg intensity on Yermak Plateau. Second, we will briefly summarize recent studies discussing differences between sediment transported by icebergs or by sea ice. Finally, we will present an interpretation of the preliminary results of this study with respect to our understanding of the glacial history of the Svalbard and Barents Sea ice sheets.

\section{Particle Counting Using X-radiographs}

The X-ray method presented in this study is similar in many respects to the method described by Grobe (1987), who used X-radiographs (10 cm wide) prepared from $1-\mathrm{cm}$ slabs of sediment cores to count ice-rafted particles in the gravel $(>2 \mathrm{~mm})$ fraction of glaciomarine sediments. A similar type of study, based on the interpretation of X-radiographs and counts of the gravel fraction in cores, was used 

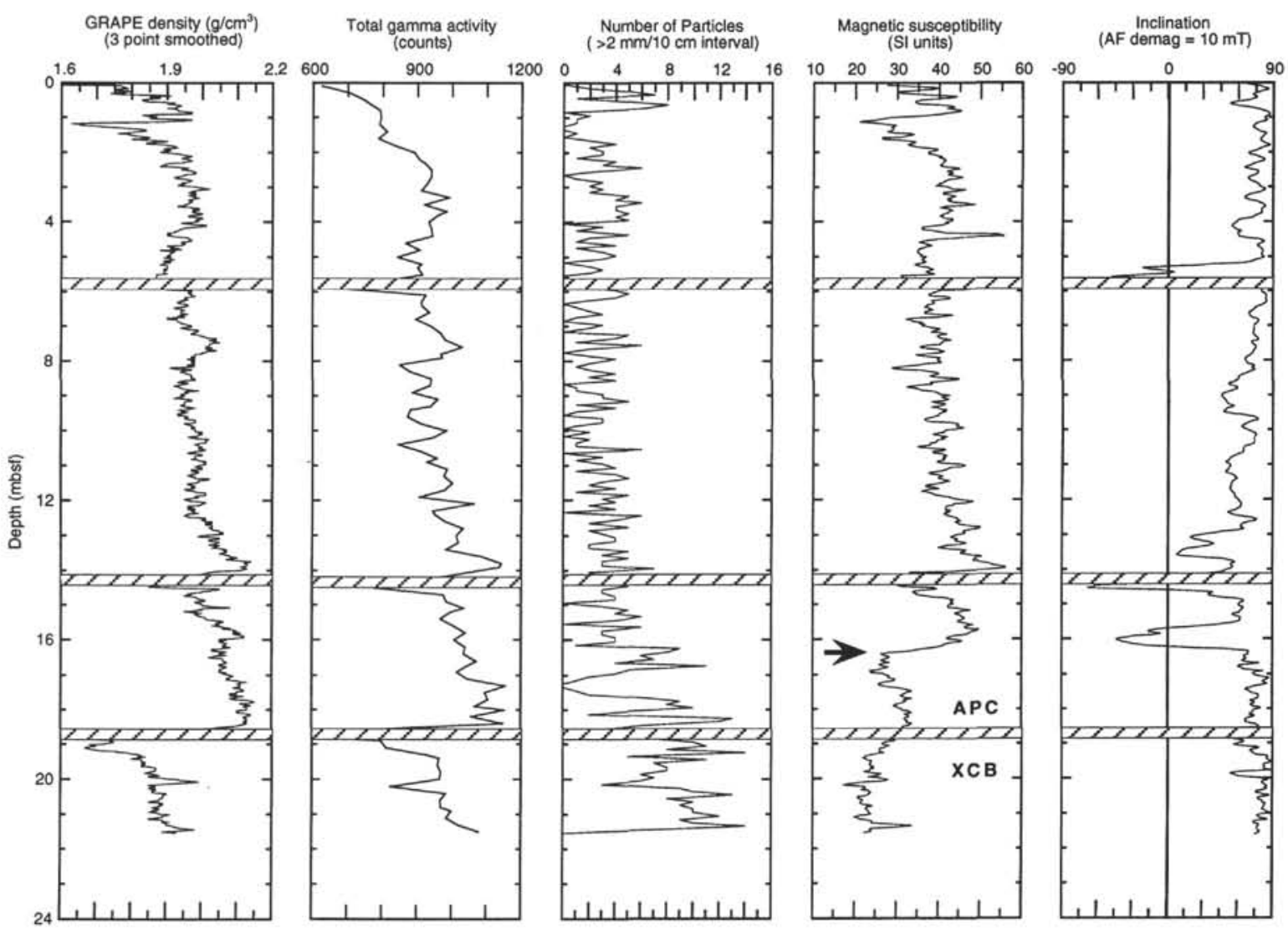

Figure 10. Summary plots of whole-core measurements of GRAPE bulk density, total gamma activity, and magnetic susceptibility made on Cores 151-910D-1H through 4X (Myhre, Thiede, Firth, et al., 1995). Video X-ray images have been used to count the number of particles ( $>2 \mathrm{~mm}$ ) within each 10-cm-long interval of core. The natural remanent magnetization (NMR) inclination of these whole-round cores (after alternating field [AF] demagnetization to $10 \mathrm{mT}$ ) is also shown. Regions of diagonal shading indicate core boundaries. The solid arrow indicates a horizon that may provide a possible correlation between Holes $910 \mathrm{D}$ and $910 \mathrm{~A}$ (see Fig. 3). Note the increased numbers of particles ( $>2 \mathrm{~mm}$ ) observed below about $16 \mathrm{mbsf}$, in Cores 151-910D-3H and 4X; the matrix sediment recovered from this interval was extremely stiff. Also note the high variability in the number of particles over sub-meter scales.

to reconstruct the Holocene sedimentation history of Scoresby Sund, East Greenland (Marienfeld, 1991).

In Grobe (1987), it was recommended that this method should only be used in sediments deposited under conditions of intense iceberg activity, because a relatively high amount of larger particles might be necessary to get a significant result. This pre-condition is fulfilled at Hole 910D, owing to its location on the crest of Yermak Plateau and adjacent to the Fram Strait, where dynamic oceanographic and environmental conditions have persisted throughout several Quaternary glacial-interglacial cycles.

Grobe (1987) presented the following set of assumptions to support his method: (1) an iceberg transports sediments with a grain size distribution similar to a till; (2) ice-rafted sediments contain particles of all grain sizes, which will settle to the sea floor after melting of the ice; (3) this sediment may be influenced by post-depositional processes (i.e, resuspension and/or erosion by bottom currents) that modify the finer fraction of the bulk sediment; however, (4) independent of the modifying process, the gravel ( $>2 \mathrm{~mm}$ ) component of the sediment is not significantly transported or eroded by currents, and is thus representative of the degree of iceberg activity.

We maintain that these conditions are generally satisfied at Site 910 , although the presence of iceberg plowmarks on Yermak Plateau (Vogt et al., 1994) may suggest an additional process for the reworking of surficial sediments. In addition, northward-flowing, intermediate water depth currents in Fram Strait have moderate to low average velocities, but may have provided significant inputs of fine-grained sediment to Yermak Plateau at some times (Eiken and Hinz, 1993; Kristoffersen, 1990).
A wide variety of methods are currently used to interpret the icerafting history of terrigenous sediment in cores from the Nordic Seas. A study of sediment cores from Fram Strait simply used the $>63 \mu \mathrm{m}$ fraction of bulk sediment to indicate ice rafting (Hebbeln, 1992). The $125-500-\mu \mathrm{m}$ fraction of the bulk sediment was used to conduct particle counts in several studies of marine sediments from the Norwegian Sea, because it was assumed that data from this subfraction may best represent the major changes in biogenic and terrigenous coarsefraction components (Henrich, 1989; Henrich et al., 1989; Baumann et al., 1995; among others). Another study used the $>0.315 \mathrm{~mm}$ fraction to divide iceberg-rafted from sea-ice-rafted debris, because it was asserted that sea ice rarely contains particles greater than $0.3 \mathrm{~mm}$ (Kuhlemann et al., 1993). Bischof (1994) used the $>0.5 \mathrm{~mm}$ fraction in sediment cores to analyze the petrology and mineralogy of ice-rafted lithic clasts in late Quaternary deep-sea sediments of the Norwegian-Greenland Sea and to determine the provenance of groups of dropstones.

The broad range of size fractions used in these studies suggests that our decision to count clasts $>2 \mathrm{~mm}$ in diameter in the X-ray images is not unreasonable, and we maintain that these counts should provide a good first-order estimate of changes in the intensity of ice rafting in the vicinity of Site 910 on Yermak Plateau, as well as additional information regarding changes in depositional environment.

\section{Sediment Transport by Icebergs and Sea Ice}

Much of the material accumulating on the sea floor of the northern regions of the Nordic Seas and Arctic Ocean is composed of terrige- 
A

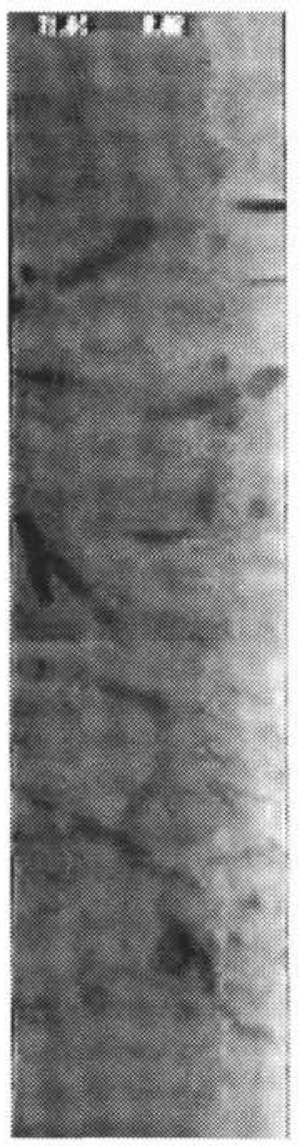

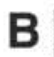

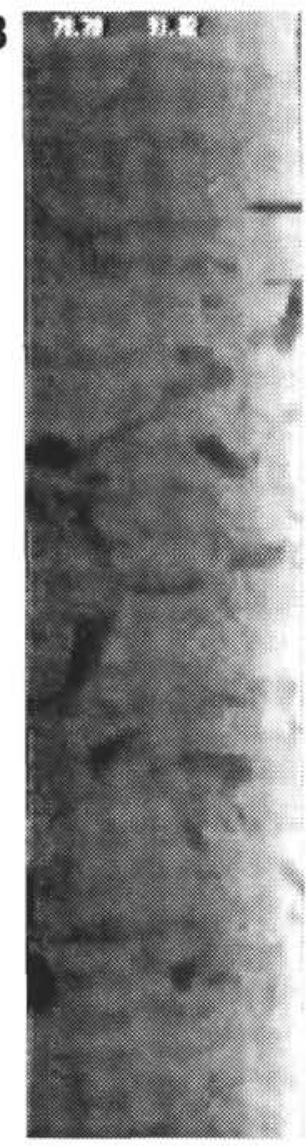

Figure 11. A. An enhanced digital video image of Section 151-910D-10X-2, near $70 \mathrm{~cm}$, at zero degrees of rotation, showing the abundance of burrows in the sediment. The distinct aspect of these burrows in the X-ray images may suggest that they have pyritized linings. B. An enhanced digital video image of the same section of core after being rotated $90^{\circ}$ around its long axis.

nous sediment transported from the surrounding continental margins by icebergs and/or sea ice. Our ability to interpret the sedimentary record relies on an understanding of the differences between these two processes. It is also important to understand how the relative contributions from these processes may have changed during glacial and interglacial periods.

Studies of sediment contained in sea ice have shown that significant amounts of sediment can be transported to the deep ocean by this mechanism (Reimnitz et al., 1993a, 1993b; Nürnberg et al., 1994; and references therein), but that major differences are seen in sediment transport regimes from different regions of the Arctic Ocean (Reimnitz et al., 1994).

Nürnberg et al., (1994) suggests that sediments carried in presentday sea ice in the eastern Arctic Ocean are likely to be fine grained (i.e., dominated by silt and clay), although sand and gravel up to $5 \mathrm{~cm}$ in diameter are sometimes found. Studies of the distribution of clay minerals in Arctic Ocean sediments provide information about the source regions and transport mechanisms for fine-grained sedimentary material contained in sea ice (Stein et al., 1994). In future studies of the Hole 910D cores, significant insights might be gained from downhole clay mineral analyses of sediment samples to show how sediment sources may have changes between glacial and interglacial periods.

Cohesive sediment pellets formed by freeze-thaw processes may also constitute a significant portion of sea-ice sediments in some instances (Pfirman et al., 1989), but differentiation between sea ice and iceberg-rafted pellets is difficult (Goldschmidt et al., 1992). There are indications that cohesive sediment pellets may be present in Core 151-910D-1H and in other intervals of Hole 910D, but they are difficult to identify at this time because of the weak contrast between these clasts and the surrounding matrix material in the video X-ray images.

At present, the content and distribution of debris clasts in Spitsbergen icebergs varies widely, but much of the ice-rafted debris may be concentrated in debris-rich basal layers of ice (Dowdeswell, 1989). The main sedimentological parameter varying from one Spitsbergen iceberg to another is clast shape, depending on whether the clasts come from the base of glaciers or were the product of rock weathering processes (Dowdeswell and Dowdeswell, 1989). Valley glaciers ending in tide water are the most common in the fjords of western and northern Spitsbergen, but ice caps and large outlet glaciers are dominant in eastern Svalbard, where tabular icebergs with long axes up to $600 \mathrm{~m}$ have been observed (Dowdeswell, 1989). Documented changes in the shapes of clasts in Hole 910D may provide additional information regarding the possible source regions and transport paths of these materials.

\section{Glacial History of Yermak Plateau from Hole 910D}

The major difficulty in developing an interpretation of the particle counts from Hole 910D is the lack of an established chronology with sufficient temporal resolution to identify glacial-interglacial cycles. Flower (this volume) present a stable isotopic stratigraphy for Hole 910A that helps to constrain the age of sediments in Hole 910D, based on our correlations between these two holes (Figs. 3 and 10). In Figure 12, we compare counts of the number of clasts $(>2 \mathrm{~mm} / 10$ $\mathrm{cm}$ interval) from the upper $4 \mathrm{~m}$ of Hole 910D (Fig. 12) with the generalized glacial history of Svalbard (Mangerud and Svendsen, 1992), which includes significant ice-rafting peaks observed in Fram Strait (Hebbeln, 1992). We base this comparison on the assumption that significant advances of glaciers on Svalbard will be reflected in the sediment record to the northwest at Hole 910D. The timing of glacial advances and retreats Svalbard is largely interpreted from till sequences interbedded with marine sediments at Kapp Ekholm in central Spitsbergen (Mangerud and Svendsen, 1992).

The data presented in Figure 12 demonstrate that there is a strong general correspondence between the graphical representation of the glacial history of Svalbard and the variations in clasts concentrations in Hole 910D. The major difference between the Hole 910D data and the glacial interpretation (Mangerud and Svendsen, 1992) is reflected in the mismatch between the duration of Glaciation $\mathrm{E}$ and the presence of additional peaks in the data from Hole 910D (Fig. 12). Interestingly, Mangerud and Svendsen (1992) conclude "that the only stratigraphic level where a glacial cycle might possibly be missing is the time interval between Formation D and Till E." Further, they note that either, Glaciation E may have lasted as long as 40,000 years, the section was submerged for a considerable part of that period, or that there may have been more glaciations than are recorded during that period, with an integrated duration of around 40,000 years in the Kapp Ekholm section (Mangerud and Svendsen, 1992).

We have selected the interval from the seafloor to $4 \mathrm{mbsf}$, based on the general characteristics of the particle count variations over this interval, and because the interpretation of the stable isotopic record from Hole $910 \mathrm{~A}$ (Flower, this volume) suggests that the boundary between oxygen isotope Stages $6 / 7$ is located at about 4 mbsf in Hole 910A. Further detailed analysis of the record at Hole 910D will be presented in future studies.

We suggest that the majority of the clasts $(>2 \mathrm{~mm})$ in Hole 910D were transported there by icebergs that may have originated from northern Svalbard and/or from eastern regions of the shelf toward Franz-Josef-Land. This view may be supported by the presence of iceberg plowmarks on Yermak Plateau with southwest trends indicating that they originated "updrift" from the Yermak area (Vogt et al., 1994). This view may also be supported by relative sea-level data from Franz-Josef-Land and northern Novaya Zemlya, Russia, which 


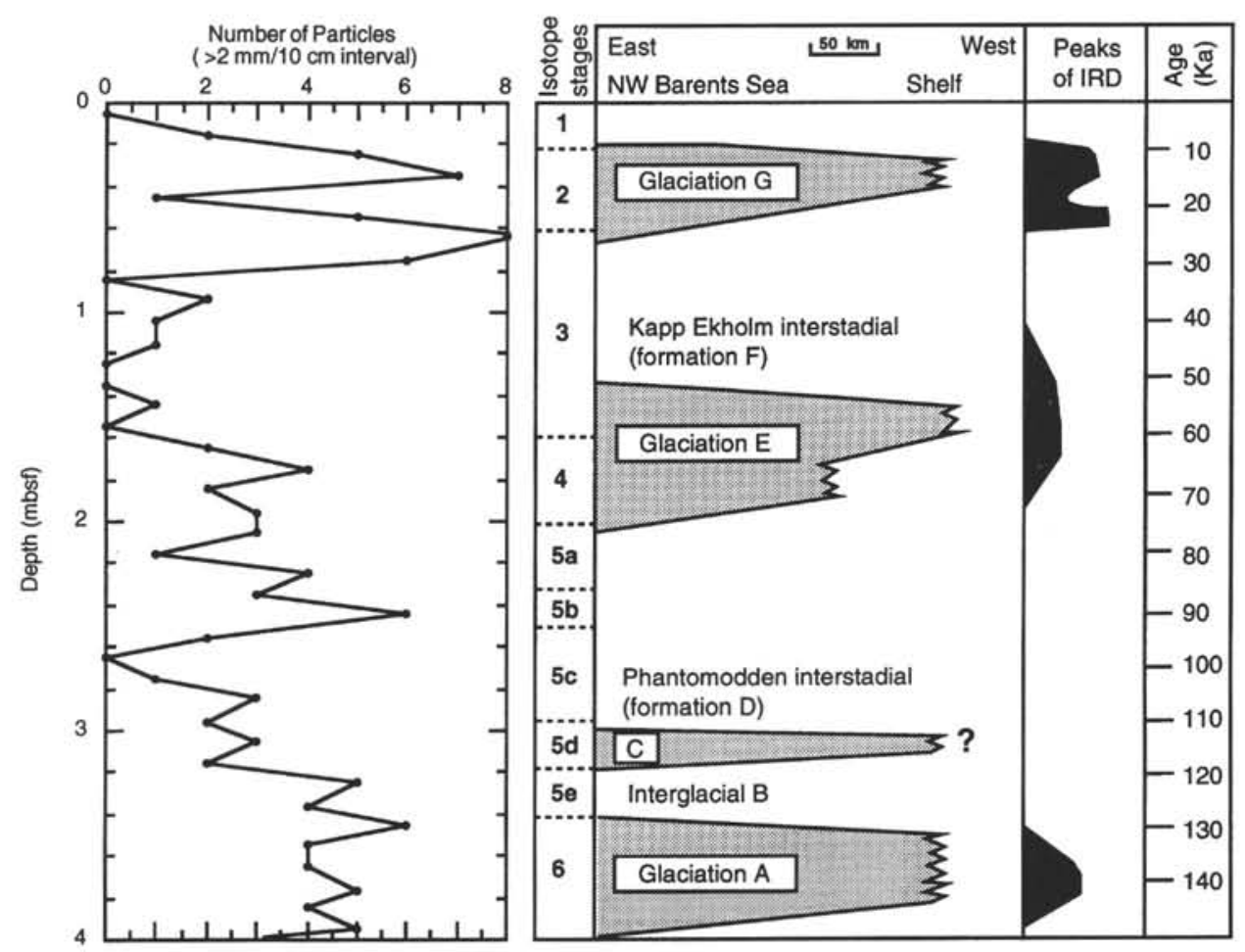

Figure 12. A speculative correlation between variations in the number of particles $>2 \mathrm{~mm}$ (per 10-cm interval) counted in X-ray images from the upper $4 \mathrm{mbsf}$ of Hole 910D, and the generalized glacial history of Svalbard (Mangerud and Svendsen, 1992). The chronology of the generalized glaciation history is primarily based on the vertical successions of facies at Kapp Ekholm in central Spitsbergen, where four major glacial-deglacial cycles are found. Peaks of ice-rafted material (IRD) in deep-sea cores collected to the west of Svalbard (Hebbeln, 1992) are also shown for comparison.

suggests that the thickest glacial loads from the Barents ice sheet were centered in the northern Barents Sea between Svalbard and Franz-Josef-Land during the last glacial maximum (Forman et al., 1995). This paleo-ice sheet may have calved deep-draft icebergs into the Arctic Ocean and funneled ice through the fjords and sounds on Svalbard to the northern shelf edge (Vogt et al., 1994; Forman et al., 1995; Lambeck, 1995).

Deep draft icebergs are known to produce seafloor scours and massive diamicton facies on the East Greenland continental margin (Dowdeswell et al., 1992; 1993; 1994). The studies of Greenland deposits may help to provide insight into glacial processes north of Svalbard and across Yermak Plateau during major glacial advances; these processes may be important for explaining the deposition of the stiff diamicton observed at Site 910.

The magnitude of the overconsolidation in the stiff diamicton from Hole 910D is presently under investigation; however, consolidation test results derived from a small sample of Core 151-910D$6 \mathrm{X}$, indicate an overconsolidation ratio of about 2 (A. Solheim, Norwegian Polar Institute, pers. comm., 1995), suggesting moderate overconsolidation rather than massive ice loading.

\section{Future Developments and Recommendations}

Improvements in the AGC/BIO X-ray system are now underway to provide the capability for direct digital capture of X-ray image data and to improve the accuracy of downcore navigation. These design improvements will allow researchers to enhance the quality of the captured images and to develop more quantitative methods of interpreting the huge amounts of data that can be collected in this fashion.

The X-ray imaging results from Hole 910D provide a pilot study, which has been used to demonstrate the potential of additional wholecore investigations following future ODP legs. This technique is highly useful for imaging sediments from high-latitude environments and from other regions where grain size is one of the primary variables influencing sediment physical properties and geophysical parameters. The long-term potential of nondestructive, whole-core imaging techniques could be realized by deploying this kind of automated X-ray imaging system, possibly as a containerized unit, on a drillship or vessel of opportunity. The data and images produced by this procedure could be archived and distributed on CD-ROM media to provide the ground-truth for many other types of sedimentary analyses and investigations.

\section{CONCLUSIONS}

Hole 910D has provided material for collecting video X-ray images and written descriptions of $96 \mathrm{~m}$ of whole-round core; these images and descriptions were acquired in less than one week of equipment usage time. The image collection required the use of a vertically oriented, continuous, whole-core X-ray imaging system to non-destructively scan and describe individual $1.5-\mathrm{m}$ sections of core through the liner. These images were simultaneously recorded on videotape for subsequent analysis and for use in digital capture and image enhancement activities. To our knowledge, this is the first time that this kind of study has been systematically conducted on DSDP/ ODP cores, and we contend that the results obtained are highly useful for fulfilling some of the primary scientific objectives of Leg 151.

We have demonstrated that counts of clasts $>2 \mathrm{~mm}$ in video X-ray images can rapidly provide sedimentary ground truth for multisensor datasets, and that these counts can be used to interpret changes in paleoenvironments and depositional regimes. However, it is clear that destructive techniques are also needed to interpret the data collected by the X-ray imaging of cores. 
The particle counts made at Hole 910D on the Yermak Plateau suggest the great potential of future studies for extending the present understanding of glacial-interglacial fluctuations of the Svalbard and Barents Sea ice sheets. Our preliminary comparison of the upper part of Hole 910D with the known glacial history of Svalbard over the past 150,000 years is intriguing, and will be pursued in future work. We believe that the increases in clast abundances will be shown to correlate with the four major advances of ice from Svalbard glaciers and may provide additional information about the marine extension of these events into the Arctic Ocean, both from Svalbard and from eastern regions.

The identification of significant variations in clast concentrations in Cores 151-910D-3H and 4X suggest a major northward advance of ice into the Arctic Ocean north of Svalbard sometime before 400,000 years ago. This event may be liked to the possible grounding of icebergs or a floating ice shelf on the crest of Yermak Plateau as proposed by Vogt et al. (1993), although we cannot confirm a grounding event based on our present understanding of this data.

\section{ACKNOWLEDGMENTS}

We wish to thank Annik Myhre, Jörn Thiede, Jan Bloemendal, Benjamin Flower, Julie Hood, Suzanne O'Connell, and Thomas Wolf-Welling for discussions relating to this study. We thank Bob Olivas, Chris Mato, Iris Hardy and Kate Jarrett for their assistance during the course of this project. We also thank John King for providing the cryogenic magnetometer used in this study. Comments from Anders Solheim and Joar Sættem significantly improved the focus of this paper. This is a contribution to the Climate System History and Dynamics (CSHD) program, sponsored by the Natural Sciences and Engineering Research Council of Canada (NSERC) and the Atmospheric and Environment Service (AES).

\section{REFERENCES}

Aagaard, K., Swift, J.H., and Carmack, E.C., 1985. Thermohaline circulation in the Arctic Mediterranean seas. J. Geophys. Res., 90:4833-4846

Andersen, E.S., Solheim, A., and Elverhøi, A., 1992. Development of a glaciated Arctic continental margin: exemplified by the western margin of Svalbard. ICAM Proc.: Int. Conf. on Arctic Margins, 155-160.

Baumann, K.-H., Lackschewitz, K.S., Mangerud, J., Spielhagen, R.F., WolfWelling, T.C.W., Henrich, R., and Kassens, H., 1995. Reflection of Scandinavian ice sheet fluctuations in Norwegian Sea sediments during the past 150,000 years. Quat. Res., 43:185-197.

Bischof, J.F., 1994. The decay of the Barents ice sheet as documented in nordic seas ice-rafted debris. Mar. Geol., 117:35-55.

Boulton, G.S., 1979. Glacial history of the Spitsbergen archipelago and the problem of a Barents Shelf ice sheet. Boreas, 8:31-57.

Bouma, A.H., 1979. Methods for the Study of Sedimentary Structures: Huntington, NY (R.E. Kreiger).

Denton, G., and Hughes, T., 1981. The Arctic Ice Sheet: an outrageous hypothesis. In Denton, G.H., and Hughes, T. (Eds.), The Last Great Ice Sheet: New York (John Wiley), 437-467.

Dowdeswell, J.A., 1989. On the nature of Svalbard icebergs. J. Glaciol., $35: 224-234$.

Dowdeswell, J.A., and Dowdeswell, E.K., 1989. Debris in icebergs and rates of glaci-marine sedimentation: observations from Spitsbergen and a simple model. J. Geol., 97:221-231.

Dowdeswell, J.A., Villinger, H., Whittington, R.J., and Marienfeld, P., 1993. Iceberg scouring in Scoresby Sund and on the East Greenland continental shelf. Mar. Geol., 111:37-53.

Dowdeswell, J.A., Whittington, R.J., and Hodgkins, R., 1992. The sizes, frequencies, and freeboards of East Greenland Icebergs observed using ship radar and sextant. J. Geophys. Res., 97:3515-3528.

Dowdeswell, J.A., Whittington, R.J., and Marienfeld, P., 1994. The origin of massive diamicton facies by iceberg rafting and scouring, Scoresby Sund, East Greenland. Sedimentology, 41:21-35.

Eidvin, T., Jansen, E., and Riis, F., 1993. Chronology of Tertiary fan deposits off the western Barents Sea: implications for the uplift and erosion history of the Barents shelf. Mar. Geol., 112:109-131.
Eiken, O., and Hinz, K., 1993. Contourites in the Fram Strait. Sediment. Geology, 82:15-32.

Elverhøi, A., 1984. Glacigenic and associated marine sediments in the Weddell Sea, fjords of Spitsbergen and the Barents Sea: a review. Mar. Geol. 57:53-88.

Elverhøi, A., Fjeldskaar, W., Solheim, A., Nyland-Berg, M., and Russwurm, L., 1993. The Barents Ice Sheet: a model of its growth and decay during the last glacial maximum. Quat. Sci. Rev., 12:863-873.

Elverhøi, A., and Solheim, A., 1983. The Barents Sea Ice Sheet: a sedimentologic discussion. Polar Res., 1:23-42.

, 1987. Late Weichselian glaciation of the northern Barents Sea: a discussion. Polar Res., 5:127-149.

Forman, S.L., 1989. Late Weichselian glaciation and deglaciation of Forlandsundet area, western Spitsbergen, Svalbard. Boreas, 18:51-60.

, 1990. Post-glacial relative sea-level history of northwest Spitsbergen, Svalbard. Geol. Soc. Am. Bull., 102:1580-1590.

Forman, S.L., Lubinski, D., Miller, G.H., Matishov, G., Korsun, S., and Myslivets, V., 1995. Postglacial emergence and distribution of late Weichselian ice-sheet loads in the northern Barents and Kara Seas, Russia. Geology, 23:113-116.

Goldschmidt, P.M, Pfirman, S.L., Wollenburg, I., and Henrich, R., 1992. Origin of sediment pellets from the Arctic seafloor: sea ice or icebergs? Deep-Sea Res., 39:S539-S565.

Grobe, H., 1987. A simple method for the determination of ice-rafted debris in sediment cores. Polarforschung, 57:123-126.

Grosswald, M.G., 1980. Late Weichselian Ice Sheet of Northern Eurasia. Quat. Res., 13:1-32

, 1993. Extent and melting history of the Late Weichselian ice sheet, the Barents-Kara Continental Margin. In Peltier, W.R. (Ed.), Ice in the Climate System: Berlin (Springer-Verlag), NATO ASI Series, 12:120.

Hebbeln, D., 1992. Weichselian glacial history of the Svalbard area: correlating the marine and terrestrial records. Boreas, 21:295-304.

Hebbeln, D., Dokken, T., Andersen, E.S., Hald, M., and Elverhøi, A., 1994. Moisture supply for northern ice-sheet growth during the Last Glacial Maximum. Nature, 370:357-360.

Hopkins, T.S., 1991. The GIN Sea - a synthesis of its physical oceanography and literature review 1972-1985. Earth-Sci. Rev., 30:175-318.

Hunkins, K., 1990. A review of the physical oceanography of Fram Strait. In Pratt, L.J. (Ed.), The Physical Oceanography of Sea Straits: Dordrecht (Kluwer Acad. Publ.), 61-93.

Jones, G.A., and Keigwin, L.D., 1988. Evidence from Fram Strait $\left(78^{\circ} \mathrm{N}\right)$ for early deglaciation. Nature, 336:56-59.

Kristoffersen, Y., 1990. On the tectonic evolution and paleoceanographic significance of the Fram Strait gateway. In Bleil, U., and Thiede, J. (Eds.), Geological History of the Polar Oceans: Arctic versus Antarctic. NATO ASI Ser., Ser. C, 308:63-76.

Lambeck, K., 1995. Constraints on the Late Weichselian ice sheet over the Barents Sea from observations of raised shorelines. Quat. Sci. Rev., 14:116.

Lehman, S.J., and Forman, S.L., 1992. Late Weichselian glacier retreat in Kongsfjorden, West Spitsbergen, Svalbard. Quat. Res., 37:139-154.

Mangerud, J., Bolstad, M., Elgersma, A., Helliksen, D., Landvik, J.Y., Lønne, I., Lycke, A.K., Salvigsen, O., Sandahl, T., and Svendsen, J.I. 1992. The last glacial maximum on Spitsbergen, Svalbard. Quat. Res., 38:1-31.

Mangerud, J., and Svendsen, J.I., 1990. Deglaciation chronology inferred from marine sediments in a proglacial lake basin, western Spitsbergen, Svalbard. Boreas, 19:249-272.

, 1992. The last interglacial-glacial period on Spitsbergen, Svalbard. Quat. Sci. Rev, 11:633-664.

Manley, T.O., Bourke, R.H., and Hunkins, K.L., 1992. Near-surface circulation over the Yermak Plateau in northern Fram Strait. J. Mar. Sys., 3:107125 .

Marienfeld, P., 1991. Marine geological work in Scoresby Sund, East Greenland: preliminary results of R/V Polarstern Cruises ARK-V/3b and ARKVII/3b. In Möller, P., Hjort, C., and Ingólfsson, Ó. (Eds.), The Last Interglacial-Glacial Cycle: Preliminary Report on the PONAM Fieldwork in Jameson Land and Scoresby Sund, East Greenland. LUNDQUA Rep., 33:157-163.

Miller, G.H., Sejrup, H.P., Lehman, S.J., and Forman, S.L., 1989. Glacial history and marine environmental change during the last interglacial-glacial cycle, western Spitsbergen, Svalbard. Boreas, 18:273-296.

Myhre, A.M., Thiede, J., Firth, J.V., et al., 1995. Proc. ODP, Init. Repts., 151: College Station, TX (Ocean Drilling Program). 
Nürnberg, D., Wollenburg, I., Dethleff, D., Eicken, H., Kassens, H., Letzig, T., Reimnitz, E., and Thiede, J., 1994. Sediments in Arctic sea ice: implications for entrainment, transport and release. Mar. Geol., 119:185-214.

Pfirman, S., Wollenburg, I., Thiede, J., and Lange, M.A., 1989. Lithogenic sediment on Arctic pack ice: potential aeolian flux and contribution to deep sea sediments. In Leinen, M., and Sarnthein, M. (Eds.), Paleoclimatology and Paleometeorology: Modern and Past Patterns of Global Atmospheric Transport: Boston (Kluwer Academic), 463-493.

Polyak, L., Lehman, S.J., Gataullin, V., and Jull, A.J.T., 1995. Two-step deglaciation of the southeastern Barents Sea. Geology, 23:567-571.

Reimnitz, E., Barnes, P.W., and Weber, W.S., 1993a. Particulate matter in pack ice of the Beaufort Gyre. J. Glaciol., 39:186-198.

Reimnitz, E., Dethleff, D., and Nürnberg, D., 1994. Contrasts in Arctic shelf sea-ice regimes and some implications: Beaufort Sea versus Laptev Sea. Mar. Geol., 119:215-225.

Reimnitz, E., McCormick, M., McDougall, K., and Brouwers, E., 1993b. Sediment export by ice rafting from a coastal polynya, Arctic Alaska, U.S.A. Arct. Alp. Res., 25:83-98.

Salvigsen, O., 1979. The last deglaciation of Svalbard. Boreas, 8:229-231.

Salvigsen, O., and Österholm, H., 1982. Radiocarbon dated raised beaches and glacial history of the northern coast of Spitsbergen, Svalbard. Polar Res., 1:97-115.

Solheim, A., Milliman, J.D., and Elverhøi, A., 1988. Sediment distribution and sea floor morphology of Storbanken: implications for the glacial history of the northern Barents Sea. Can. J. Earth Sci., 25:547-556.
Solheim, A., Russwurm, L., Elverhøi, A., and Berg, M.N., 1990. Glacial geomorphic features in the northern Barents Sea: direct evidence for grounded ice and implications for the pattern of deglaciation and late glacial sedimentation. In Dowdeswell, J.A., and Scourse, J.D. (Eds.), Glacimarine Environments: Processes and Sediments. Geol. Soc. Spec. Pub. London, 53:253-268.

Stein, R., Grobe, H., and Wahsner, M., 1994. Organic carbon, carbonate, and clay mineral distributions in eastern central Arctic Ocean surface sediments. Mar. Geol., 119:269-285.

Svendsen, J.I., and Mangerud, J., 1992. Paleoclimatic inferences from glacial fluctuations on Svalvard during the last 20,000 years. Clim. Dyn., 6:213220.

Svendsen, J.I., Mangerud, J., Elverhøi, A., Solheim, A., and Schuttenhelm, R.T.E., 1992. The Late Weichselian glacial maximum on western Spitsbergen inferred from offshore sediment cores. Mar. Geol., 104:1-17.

Vogt, P.R., Crane, K., and Sundvor, E., 1994. Deep Pleistocene iceberg plowmarks on the Yermak Plateau: sidescan and $3.5 \mathrm{kHz}$ evidence for thick calving ice fronts and a possible marine ice sheet in the Arctic Ocean. Geology, 22:403-406.

Date of initial receipt: 6 July 1995

Date of acceptance: 5 February 1996

Ms 151SR-129 